\title{
Rooting of stem cuttings of Populus $x$ euramericana under different water potentials
}

\author{
S. Puri ${ }^{1}$ and F.B. Thompson 2 \\ 1 Department of Forestry, Haryana Agriculture University, Hisar 125 004, India, and \\ 2 Oxford Forestry Institute, South Parks Road, Oxford OX1 3RB, U.K.
}

\section{Introduction}

The rooting of stem cuttings is affected by many environmental factors (Haissig. 1974; Puri and Shamet, 1988). The maintenance of water balance is one of the important factors. The water balance of cuttings is affected by high transpirational water losses coupled with either low water absorption or slow water transport through the conducting tissues. However, little is known about maintenance and control of plant water potential during the rooting of cuttings. The present studies were undertaken to examine rooting as influenced by initial plant water potential.

\section{Materials and Methods}

Variation in the initial plant water potential $\left(\Psi_{\mathrm{p}}\right)$ of Populus $x$ euramericana was obtained by 3 pretreatments, viz., fresh, soaked (5 d in water) and dried ( $7 \mathrm{~d}$ old cuttings kept in the open). Initial $\psi_{\mathrm{p}}$ were $-1.45,-0.1$ and $-2.1 \mathrm{MPa}$, respectively. Cuttings were planted in a mixture of peat and grit sand $(1: 1, v / v)$, maintained at -0.006 and $-0.06 \mathrm{MPa}$ by weighing the pots daily and adding water to restore these soil moisture polentials. Tensiometers were also used as a check. The pots with cuttings were kept in a growth chamber at $25^{\circ} \mathrm{C}, \mathrm{RH}$ at $70 \%$ and illumination of 1000 foot candles for $16 \mathrm{~h}$. The cuttings were assessed for shoot and root development, moisture content, water and osmotic potentials, stomatal diffusion resistance, relative conductivity and starch content.

Water potentials of shoots ( $\Psi$ shoot) were measured with a pressure chamber (Scholander et al., 1964) and those of bark ( $\Psi$ bark) according to the Shardakov method. Osmotic potential ( $\Psi$ solute) was measured with a Wescor C52 chamber hygrometer connected to a Wescor HR-33 T microvolt meter. The relative conductivity of the root system and base of each cutting was estimated according to the procedures of lkeda and Suzaki (1984). Starch was extracted from the stem following the method of Dekker and Richards (1971) and was estimated after hydrolysis to glucose by the method of Kilburn and Taylor (1969). Results were subjected to a standard analysis of variance procedure using a split plot design.

\section{Results and Discussion}

Root initiation per se in poplar is not an obstacle to propagation, but moisture supply has a major effect on successful rooting. The water stressed cuttings had fewer roots and these grew slowly (both in number and length) as shown in Table I. Presoaking stimulated rooting and enabled 
Table I. Changes in shoot water potential, osmotic potential, relative conductivity, starch, root number and root length in poplar cuttings subjected to 3 pretreatments and planted in two soils with different moisture potentials.

\begin{tabular}{|c|c|c|c|c|c|c|c|}
\hline \multirow[t]{2}{*}{ Measurements } & \multirow[t]{2}{*}{ Day } & \multicolumn{3}{|c|}{ Soil at $-0.006 \mathrm{MPa}$} & \multicolumn{3}{|c|}{ Soil at $-0.06 \mathrm{MPa}$} \\
\hline & & fresh & soaked & dried & fresh & soaked & dried \\
\hline $\begin{array}{l}\text { Shool water } \\
\text { potential (MPa) }\end{array}$ & $\begin{array}{r}0 \\
5 \\
25\end{array}$ & $\begin{array}{l}-1.45 a \\
-0.95 b \\
-1.00 b\end{array}$ & $\begin{array}{l}-0.10 b \\
-0.60 c \\
-1.05 a b\end{array}$ & $\begin{array}{l}-2.10 c \\
-1.10 a \\
-1.00 a b\end{array}$ & $\begin{array}{l}-1.45 a \\
-1.40 a b \\
-1.20 a c\end{array}$ & $\begin{array}{l}-0.10 b \\
-0.95 c \\
-1.20 a c\end{array}$ & $\begin{array}{l}-2.10 c \\
-1.80 a \\
-1.35 b\end{array}$ \\
\hline $\begin{array}{l}\text { Osmotic } \\
\text { potential (MPa) }\end{array}$ & $\begin{array}{r}0 \\
5 \\
25\end{array}$ & $\begin{array}{l}-2.58 a \\
-1.65 b \\
-2.83 c\end{array}$ & $\begin{array}{l}-2.37 b \\
-2.86 c \\
-3.41 a\end{array}$ & $\begin{array}{l}-4.74 c \\
-2.80 a b \\
-2.78 a b\end{array}$ & $\begin{array}{l}-2.58 \mathrm{a} \\
-4.56 \mathrm{~b} \\
-3.17 \mathrm{c}\end{array}$ & $\begin{array}{l}-2.37 b \\
-4.07 c \\
-2.42 a\end{array}$ & $\begin{array}{l}-4.74 c \\
-4.23 a \\
-3.34 b\end{array}$ \\
\hline $\begin{array}{l}\text { Relative } \\
\text { conductivity }\left(\mathrm{cm}^{2}\right)\end{array}$ & $\begin{array}{r}0 \\
5 \\
25\end{array}$ & $\begin{array}{l}0.115 a \\
0.065 a b \\
0.050 a b\end{array}$ & $\begin{array}{l}2.03 b \\
0.396 \mathrm{bc} \\
0.30 \mathrm{a}\end{array}$ & $\begin{array}{l}1.83 c \\
0.41 b c \\
0.13 b\end{array}$ & $\begin{array}{l}0.115 a \\
0.008 b \\
0.035 c\end{array}$ & $\begin{array}{l}2.03 b \\
0.06 a \\
0.06 a\end{array}$ & $\begin{array}{l}1.83 \mathrm{c} \\
0.03 a \\
0.03 a\end{array}$ \\
\hline Starch $(\% d w)$ & $\begin{array}{r}0 \\
5 \\
25\end{array}$ & $\begin{array}{l}9.2 a \\
8.3 b \\
4.8 c\end{array}$ & $\begin{array}{l}8.8 \mathrm{a} \\
8.3 \mathrm{a} \\
4.0 \mathrm{~b}\end{array}$ & $\begin{array}{l}8.9 a \\
8.6 a \\
5.3 c\end{array}$ & $\begin{array}{l}9.2 a \\
9.1 a \\
6.9 b\end{array}$ & $\begin{array}{l}8.8 a \\
8.7 a \\
6.9 b\end{array}$ & $\begin{array}{l}8.9 a \\
8.6 a \\
6.0 c\end{array}$ \\
\hline Root number & $\begin{array}{r}0 \\
5 \\
25\end{array}$ & $\begin{array}{c}0 \\
5 a \\
12 b\end{array}$ & $\begin{array}{l}0 \\
2.3 a \\
15 b\end{array}$ & $\begin{array}{c}0 \\
5 a \\
14 b\end{array}$ & $\begin{array}{l}0 \\
0 \\
8.3 b\end{array}$ & $\begin{array}{c}0 \\
5.3 a \\
10 b\end{array}$ & $\begin{array}{l}0 \\
0 \\
8.6 b\end{array}$ \\
\hline Root length $(\mathrm{cm})$ & $\begin{array}{r}0 \\
5 \\
25\end{array}$ & $\begin{array}{c}0 \\
4.2 \mathrm{a} \\
254.2 \mathrm{~b}\end{array}$ & $\begin{array}{c}0 \\
3.5 a \\
168.6 \mathrm{c}\end{array}$ & $\begin{array}{c}0 \\
11.9 \mathrm{a} \\
222.9 \mathrm{bc}\end{array}$ & $\begin{array}{c}0 \\
0 \\
51.8 \mathrm{a}\end{array}$ & $\begin{array}{l}0 \\
9.5 \mathrm{a} \\
83.6 \mathrm{a}\end{array}$ & $\begin{array}{c}0 \\
0 \\
81.6 a\end{array}$ \\
\hline
\end{tabular}

Note: values followed by the same letter do not differ significantly at $5 \%$ level.

cuttings to absorb water for initial root development, even under the drier soil conditions $(-0.06 \mathrm{MPa})$. The stem moisture of fresh and dried cuttings increased with time. The moisture content of soaked cuttings decreased initially, presumably due to high initial moisture, and later increased. The root moisture content increased initially and then decreased in all the treatments. This is attributed to the observation that, during early development of roots, only cell elongation and cell division occur, and later on cell differentiation, lignification and hardening begin (Esau, 1960).

Changes in shoot water potential, relative conductivity and starch are given in Table I. The water potential of fresh and dried cuttings increased with time but for soaked cuttings it decreased. This result may be due to the high initial $\psi$ of soaked cuttings. Once well-developed roots were formed, the $\Psi$ of shoot and bark stabilized, irrespective of pretreatment.

The turgor pressure more or less followed the pattern of $\Psi$ solute but exaggerated any rise of potential, due to the fall in $\Psi$ bark often associated with rises in osmotic potential of the expressed sap. The relative conductivity decreased initially and then increased gradually. This decrease may be due to decreased water absorption by the cuttings until the functional roots were formed. Grange and Loach (1983) opined that the decrease in water absorption of cuttings with time may be due to increased resistance to water influx through the cut surface. 
Starch acts as the prime carbohydrate source for root initiation and development (Haissig, 1974). In the present studies, it decreased with time irrespective of treatment (Table I). This decrease may be attributable to the export of starch to developing roots and leaves.

Although our observations were limited to a single species and few treatments, they suggest that the levels of water stress imposed on the cuttings significantly influenced rooting.

\section{References}

Dekker R.F.H. \& Richards G.N. (1971) Determination of starch in plant material. $J$. Sci. Food Agric. 22, 441-451
Esau K. (1960) in: Anatomy of Seed Plants. John Wiley \& Sons, New York pp. 569

Grange R.I. \& Loach K. (1983) The water economy of unrooted leafy cuttings. J. Hortic. Sci. $58,9-17$

Haissig B.E. (1974) Metabolism during adventitious root primordium initiation and development. New Zealand J. For. Sci. 4, 324-337

Ikeda T. \& Suzaki T. (1984) Distribution of xylem resistance to water flow in stems and branches of hardwood species. J. Jpn. For. Soc. 66, 229236

Kilburn D.M. \& Taylor P.M. (1969) Effect of sulfhydryl reagents on glucose determination by the glucose oxidase method. Anal. Biochem. $27,555-558$

Puri S. \& Shamet G.S. (1988) Rooting of stem cuttings of some social forestry species. Int. Tree Crops J. (U.K.) 5, 63-70

Scholander P.F., Hammel H.T., Hemmingsen E.A. \& Bradstreet E.D. (1964) Hydrostatic pressure and osmotic potentials in leaves of mangroves and some other plants. Proc. Natl. Acad. Sci. USA 51, 119-125 